\title{
Deep zooxanthellate corals at the high latitude Bermuda Seamount
}

Received: 8 September 2008/Accepted: 25 September 2008/Published online: 21 October 2008

(C) Springer-Verlag 2008
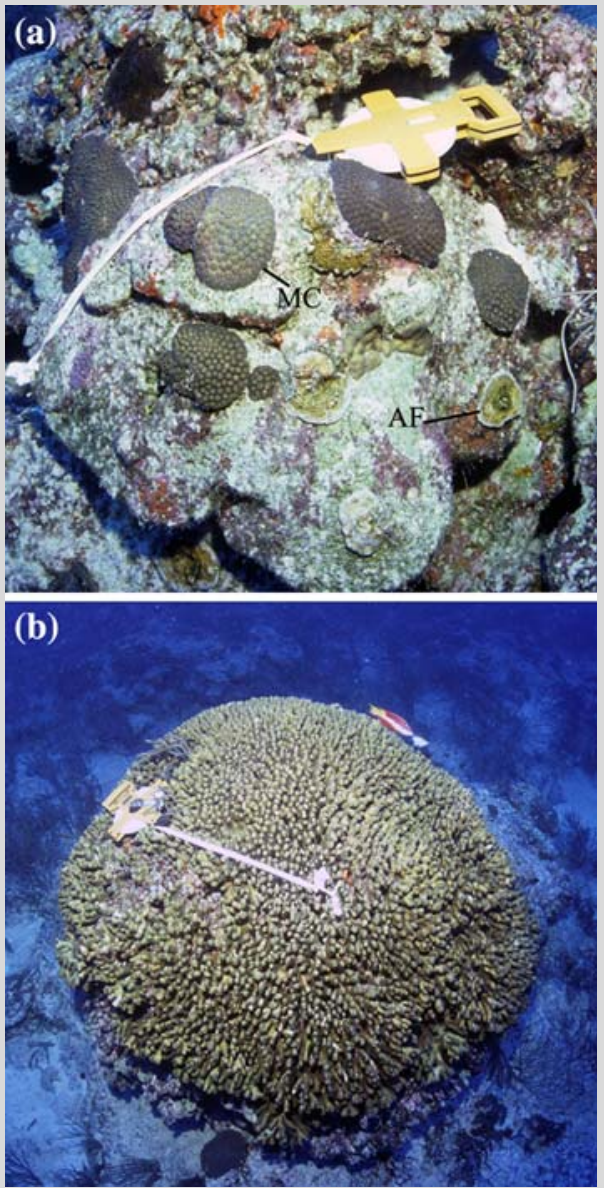

Fig. 1 a Colonies of Montastraea cavernosa (MC) and Agaricia fragilis (AF) and $\mathbf{b}$ Madracis carmabi at $55 \mathrm{~m}$ depth (scale $50 \mathrm{~cm}$ )
At $32^{\circ} \mathrm{N}$ of the equator, the reefs of Bermuda are among the most northerly in the world. Zooxanthellate scleractinian corals occur to depths of 50-70 m where they form a largely unexplored deep fore-reef slope, before giving way to rhodolith fields on the side of the seamount (Fricke and Meischner 1985). The zooxanthellate corals of the mesophotic deep fore-reef system of Bermuda thus face the physiological challenge of being at both their latitudinal and bathymetric limits.

In 2007, preliminary surveys of the Bermuda fore-reef were conducted using mixed-gas technical diving between 45 and $60 \mathrm{~m}$. The structure of the deep forereef was strikingly different to shallower terrace-reef communities. Notably the Diploria-Montastraea-Porites species assemblage that dominates coral cover around much of Bermuda was absent on the deep fore-reef. Instead, the deep forereef was dominated by Montastraea cavernosa, Agaricia fragilis, and Madracis decactis, usually as small ( $20 \mathrm{~cm}$ diameter) colonies (Fig. 1a). Occasionally, however, large ( $\sim 1 \mathrm{~m}$ diameter) colonies of the branching coral Madracis carmabi (Vermeij et al. 2003) were found at $50-55 \mathrm{~m}$ depth. This is the first recording of this scleractinian on the Bermuda reef system (Fig. 1b).

Analysis of genetic diversity of zooxanthellae from deep corals by PCR-RFLP of the small subunit rRNA gene revealed that although previous surveys have shown almost all coral species contain a single clade of zooxanthellae at shallow depths in Bermuda (Savage et al. 2002), several of these corals harbour multiclade populations at depth. These included $M$. decactis, Dichocoenia stokesi, and Meandrina meandrites, that contain clade B at shallow depths, but mixed populations of clade B and C at $45-60 \mathrm{~m}$. Recently, mixed populations of zooxanthellae have also been reported in species of Madracis on the deep reefs of Curacao (Frade et al. 2008).

Better understanding of mesophotic habitats derived from previous studies of deep reefs (e.g., Bak et al. 2005), and future research are required to assess whether they provide potential refugia from global threats of bleaching and disease that have damaged shallower coral communities.

Acknowledgments We thank the Khaled Bin Sultan Living Oceans Foundation and BIOS for funding.

\section{References}

Bak RPM, Nieuwland G, Meesters EH (2005) Coral reef crisis in deep and shallow reefs: 30 years of constancy and change in reefs of Curaco and Bonaire. Coral Reefs 24:475-479

Frade PR, De Jongh F, Vermeulen F, Van Bleijswijk J, Bak RPM (2008) Variation in symbiont distribution between closely related coral species over large depth ranges. Mol Ecol 17:691-703

Fricke H, Meischner D (1985) Depth limits of Bermudan Scleractinian corals: a submersible survey. Mar Biol 88:175-187

Savage AM, Goodson MS, Visram S, Trapido-Rosenthal HG, Wiedenmann J, Douglas AE (2002) Molecular diversity of symbiotic algae at the latitudinal margins of their distribution: dinoflagellates of the genus Symbiodinium in corals and sea anemones. Mar Ecol Prog Ser 244:17-26

Vermeij M, Diekmann OE, Bak RPM (2003) A new species of scleractinian coral (cnidaria, anthozoa), Madracis carmabi $\mathrm{n}$. sp. from the Caribbean. Bull Mar Sci 73:679-684

\section{A. A. Venn $(\bowtie)$ F. K. Weber · J. E. Loram · R. J. Jones}

Bermuda Institute of Ocean Sciences (BIOS), Ferry Reach, St. Georges GE 01, Bermuda e-mail: alex@centrescientifique.mc

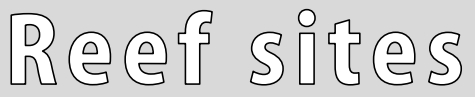

Coral Reefs (2009) 28:135 DOI $10.1007 / \mathrm{s} 00338-008-0435-\mathrm{y}$ 